\title{
Human lung, bladder and head and neck tumors as compared to their adjacent normal tissues have elevated AP-1 activity and recognize sequence elements of HIV-1 LTR
}

\author{
V. ZOUMPOURLIS ${ }^{1,2}$, E. PAPADAKIS ${ }^{1,3}$, D. DELAKAS ${ }^{2}$, A. CRANIDIS ${ }^{2}$, J. SEGAS $^{2}$, \\ H. PAPADAKIS ${ }^{2}$ and D.A. SPANDIDOS ${ }^{1,2}$ \\ ${ }^{1}$ Institute of Biological Research and Biotechnology, National Hellenic Research Foundation, Athens; \\ ${ }^{2}$ Medical School, University of Crete, Heraklion; ${ }^{3}$ Metaxa Anticancer Hospital, Pireas, Greece
}

Received November 17, 1993; Accepted December 23, 1993

\begin{abstract}
We have previously reported the specific binding of nuclear factor AP-1 isolated from human breast MDA MB 468 and HeLa cervical tumor cell lines to oligonucleotides complementary to three newly elucidated sequences within the HIV-1 LTR. These synthesized oligonucleotides, which bear high homology to the AP-1 recognition sequence, were used in the present study in gel retardation assays together with unfractionated nuclear protein extracts from human lung, bladder and head and neck tumors and adjacent normal tissue to study the role of the AP-1 protein in the regulation of HIV-1 expression. We found increased binding of AP-1 to these oligonucleotides in 9/12 lung tumors, $9 / 14$ bladder tumors and $7 / 7$ head and neck tumors as compared to adjacent normal tissues. This confirms previous results obtained when using MDA MB 468 and HeLa nuclear protein extracts. These results indicate that, AP-1 could be contributing to the HIV-1 transcriptional regulation through its interaction with the AP-1 binding sites of HIV-1 LTR.
\end{abstract}

\section{Introduction}

It is well established that the human immunodeficiency virus type 1 (HIV-1) is the main etiologic agent of acquired immunodeficiency syndrome (AIDS), which destroys the immune surveillance system and thus causes various pathological symptoms to develop (1-3). The typical long latency before onset of symptoms may be related to various stimuli or cofactors, which are involved in the disruption of the latent stage of HIV and might lead to provirus transcriptional activation. Human and viral proteins (4-6) and the oncoprotein ras p21 (7) may contribute to the transition

Correspondence to: Professor D.A. Spandidos, Institute of Biological Research and Biotechnology, National Hellenic Research Foundation, 48 Vas. Constantinou Avenue, 11635 Athens, Greece

Key words: lung tumor, bladder tumor, head and neck tumor, AP-1 activity, HIV-1 LTR sequences of HIV-1 from the latent stage to the infectious state. Different biological response modifiers (insulin, epidermal growth factor, tumor necrosis factor) $(8,9)$, hormones (hydrocortisone, dexamethasone) (8) and antitumor drugs (cis-platin, doxorubicin, daunomycin, hexamethylene bisacetamide and mitomycin $\mathrm{C}$ as opposed to carboplatin) (10-16), increase the chloramphenicol acetyl transferase expression from the HIV-1 LTR sequence in human and rat fibroblasts.

The human immunodeficiency virus type 1 long terminal repeat, HIV-1 LTR, contains binding sites for several cellular transcription factors which are implicated in HIV-1 gene expression. The regulatory sequences present upstream of the transcription initiation site $(+1)$ can be broadly categorized into proximal (promoter) and distal (enhancer) elements. The promoter element contains the TATA box, located between nucleotides -22 to -27 , which is presumably recognized by the transcription factor TFIID (17). The HIV-1 promoter also contains three GC-rich sequences, which bind to the ubiquitous transcription factor $\mathrm{Sp} 1(17,18)$. In addition to the upstream regulatory sequences, the HIV promoter contains several protein-binding sites downstream of the RNA start site. A leader binding protein (LBP-1) binds to a region from -17 to +27 and TF/NF-1 binds to a sequence from +40 to +45 (19). Furthermore, the untranslated region of the binding protein (UBP-1) has been shown to recognize HIV-1 LTR sequences from -13 to +28 of the nucleotide (20).

The HIV-1 LTR enhancer (-103 to -81 ) is recognized by EBP-1 in resting T cells (20) and NF- $x$ B (21) and HIVEN (22) in activated T-cells. cis elements include the negative regulatory element (NRE), located in the region between nucleotide positions -357 and -185 relative to the transcription initiation site +1 . The NRE contains a number of recognition sequences for cellular transcription factors such as USF, URS and NFAT-1 $(6,23)$, as well as two adjacent binding sites for the transcription factor AP-1 which are located at nucleotides -348 to -343 and -336 to 331 (24).

The AP- 1 is a family of related transcription factors encoded by the members of the jun and fos multigene families that have similar binding characteristics and sequences (25-30). The AP-1 DNA-complex is composed of homo- and heterodimers of the c-fos and c-jun family (31) 
which dimerize by interdigitation of hydrophobic helices, termed leucine-zippers (32). AP-1 can serve as both a positive and a negative regulator with respect to the expression of a variety of genes under different conditions.

The consensus DNA recognition site for AP- 1 is TGAGTCA (33). Two binding sites for transcription factor AP-1 have been mapped within the NRE of HIV-1 LTR (24). In our previous study we examined the HIV-1 LTR and identified three additional AP-1 binding sites ( -516 to -495 , 310 to -287 and +16 to +42 ) one of which was found within the TAR element. In the present study binding of AP-1 to these sites has been successfully tested in extracts from lung, bladder and head and neck tumors. The AP-1 activity is elevated in 9/12 lung tumors, in 9/14 bladder tumors and in $7 / 7$ head and neck carcinoma tumors as compared to normal human tissue. These results are in good agreement with our previous study (34) and suggest that these new HIV-1 LTR putative AP-1 sites have the same binding effect as nuclear extracts from HeLa and MDA MB 468 tumor cell lines.

\section{Materials and methods}

Preparation of cell extracts. All biopsy material was obtained from patients who had undergone lung surgery at Metaxa Hospital, Pireas, Greece or bladder and head and neck surgery at the University Hospital, Heraklion, Greece. The tissue was cut into small pieces and homogenized in $2 \mathrm{ml}$ hypotonic buffer (25 mM Tris- $\mathrm{HCl} \mathrm{pH} 7.5,5 \mathrm{mM} \mathrm{KCl}, 0.5$ $\mathrm{mM} \mathrm{MgCl}_{2}, 0.5 \mathrm{mM}$ DTT, $0.5 \mathrm{mM} \mathrm{PMSF}$ ) at $5-10 \mathrm{mg}$ protein $/ \mathrm{ml}$. The nuclei were pelleted at $2500 \mathrm{rpm}$ in a Sorvall SS34 rotor for $10 \mathrm{~min}$ at $4^{\circ} \mathrm{C}$. The pellets were washed 3 times with $2 \mathrm{ml}$ isotonic buffer (25 mM Tris- $\mathrm{Cl} \mathrm{pH} 7.5,5$ $\mathrm{mM} \mathrm{KCl,} 0.5 \mathrm{mM} \mathrm{MgCl}_{2}, 0.1 \mathrm{M}$ sucrose, $0.5 \mathrm{mM}$ DTT, 1 $\mathrm{mM}$ PMSF), resuspended in nuclei extraction buffer $(25 \mathrm{mM}$ Tris-Cl pH 7.5, 1 mM EDTA, 0.1\% NP40, 0.5 mM DTT, 0.5 $\mathrm{mM}$ PMSF) and were further clarified after centrifugation at $25000 \mathrm{rpm}$ in a Beckman Ti 50 rotor for $60 \mathrm{~min}$ at $4^{\circ} \mathrm{C}$. The supernatant was removed and the extracts were stored at $-70^{\circ} \mathrm{C}$. Protein estimation was performed as described by Bradford (35).

Preparation of double stranded oligonucleotides and retardation assays. DNA oligonucleotides were as described (34). The oligonucleotides were purified as described (34) and the double stranded oligonucleotides were 5' end-labelled using $\gamma^{32} \mathrm{P}$-ATP and T4 polynucleotide kinase and end filled using the Klenow fragment of DNA polymerase according to Maniatis et al (36).

\section{Results}

Four short DNA regions which are putative AP-1 binding sites were identified in the HIV-1 LTR (34). From these four sequences, region 2 shows the highest homology $(85.8 \%)$ to the AP-1 consensus (5'-TGAGTCA-3') and therefore the corresponding oligonucleotide hybrid $2 \mathrm{ab}$ was used in our previous studies to test the affinity of the AP-1 protein in MDA MB 468 and HeLa tumor cells. In the present study the same oligonucleotide sequence was used to examine the presence of AP-1 activity in lung, bladder and head and neck

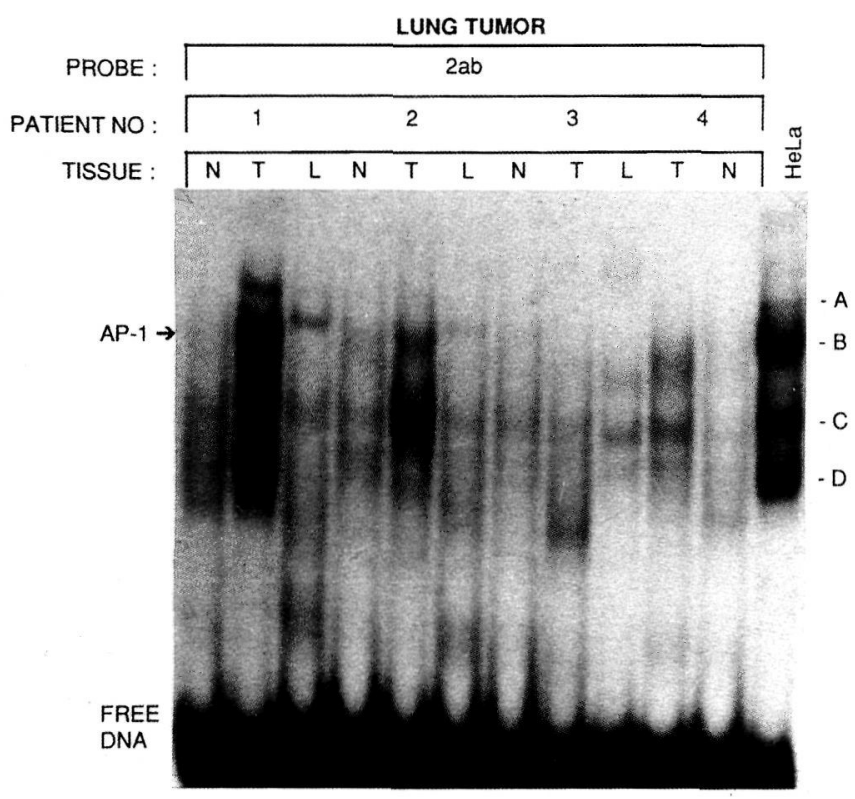

Figure 1. Electrophoretic mobility shift analysis using 2ab-AP-1 binding consensus oligonucleotide. $2000 \mathrm{cpm} \gamma^{32} \mathrm{P}$-oligo were mixed with $20 \mu \mathrm{g}$ of nuclear extracts from lung tumors, lymph nodes and adjacent normal tissues and HeLa cells. The DNA-AP-1 protein complex is indicated by the arrow. $\mathrm{N}=$ normal, $\mathrm{T}=$ tumor, $\mathrm{L}=$ lymph nodes

tumors and adjacent normal tissue. Nuclear extracts were mixed with $\gamma^{32} \mathrm{P}$-end labelled double stranded oligonucleotides $\mathrm{E}_{3} \mathrm{AP}-1$ and $2 \mathrm{ab}$, respectively and analyzing the formation of DNA-protein complexes by gel retardation assays. Twelve lung tumors were analysed and eight of them showed elevated levels of AP-1 activity as compared with either the adjacent normal tissue or the correspoding lymph nodes (Fig. 1). The same oligonucleotide hybrid, 2ab, was also used to test the presense of AP-1 activity in bladder and head and neck tumors. Nine out of fourteen bladder tumors tested showed elevated levels of AP-1 activity as compared to adjacent normal tissue (Fig. 2). Seven head and neck tumors seven tumors were analysed and all of them showed elevated AP-1 as compared with adjacent normal tissues (Fig. 3). A comparison of the data on the AP-1 activity and the pTNM in lung, bladder and head and neck tumors are shown in Tables I, II and III.

Having established that most of the examined lung and bladder tumors and all of the head and neck tumors had elevated AP-1 activity, we subsequently confirmed that the remaining non-tested AP-1-like sites (1ab,4ab) on HIV-1 LTR are functional. This was tested by employing nuclear extracts from lung tumor No 12 and bladder tumor No 1, mixed with a $\gamma^{32} \mathrm{P}$-end labelled $2 \mathrm{ab}$ or $1 \mathrm{ab}$ oligonucleotide hybrids and employing the non-labelled oligonucleotide hybrids as competitors $1 \mathrm{ab}, 2 \mathrm{ab}, 3 \mathrm{ab}, 4 \mathrm{ab}, \mathrm{E}_{3} \mathrm{AP}-1$ and analysing the formation of DNA-protein complexes by gel retardation assays. As shown in Figs. 4 (lung tumor) and 5 (bladder tumor) the non-labelled oligonucleotide hybrids $\mathrm{E}_{3} \mathrm{AP}-1,1 \mathrm{ab}, 2 \mathrm{ab}$ and $4 \mathrm{ab}$ competed with the labelled oligonucleotide hybrid 2ab for DNA-AP-1 protein complex formation. Also as shown in Fig. 6 (lung tumor) the nonlabelled oligonucleotide hybrids $1 \mathrm{ab}, 2 \mathrm{ab}$ and $\mathrm{E}_{3} \mathrm{AP}-1$ competed with the labelled oligonucleotide hybrid $1 \mathrm{ab}$ for 


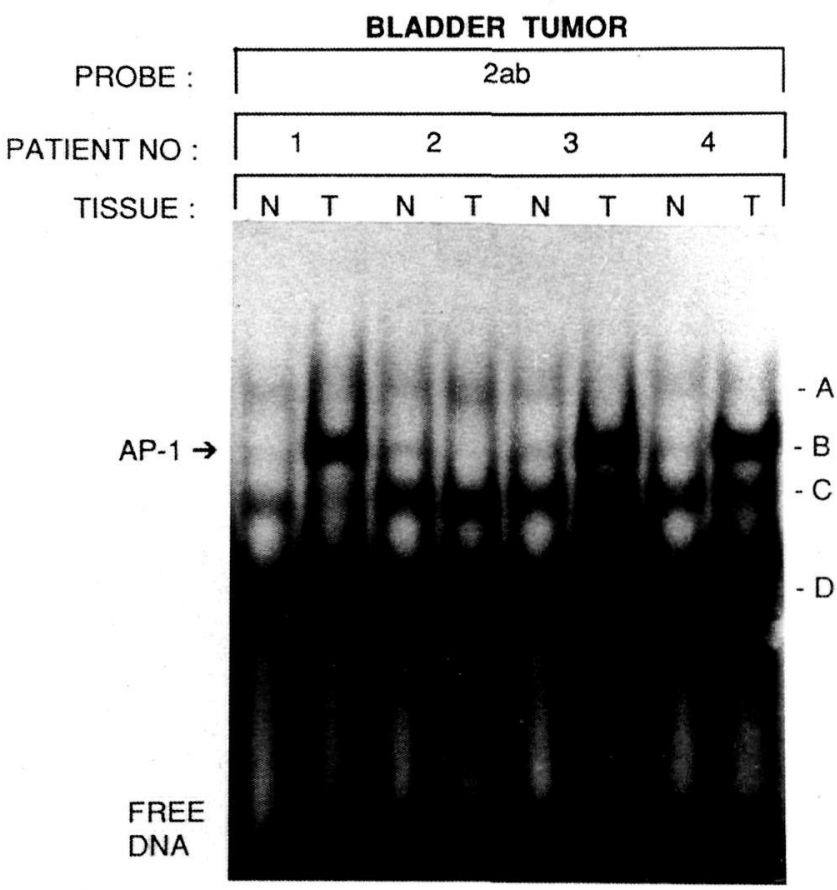

Figure 2. Electrophoretic mobility shift analysis using 2ab-AP-1 binding consensus oligonucleotide. $2000 \mathrm{cpm} \gamma^{32} \mathrm{P}$-oligo was mixed with $20 \mu \mathrm{g}$ of nuclear extracts from bladder tumors and adjacent normal tissues. The DNA-AP-1 protein complex is indicated by the arrow. $\mathrm{N}=$ normal, $\mathrm{T}=$ tumor.

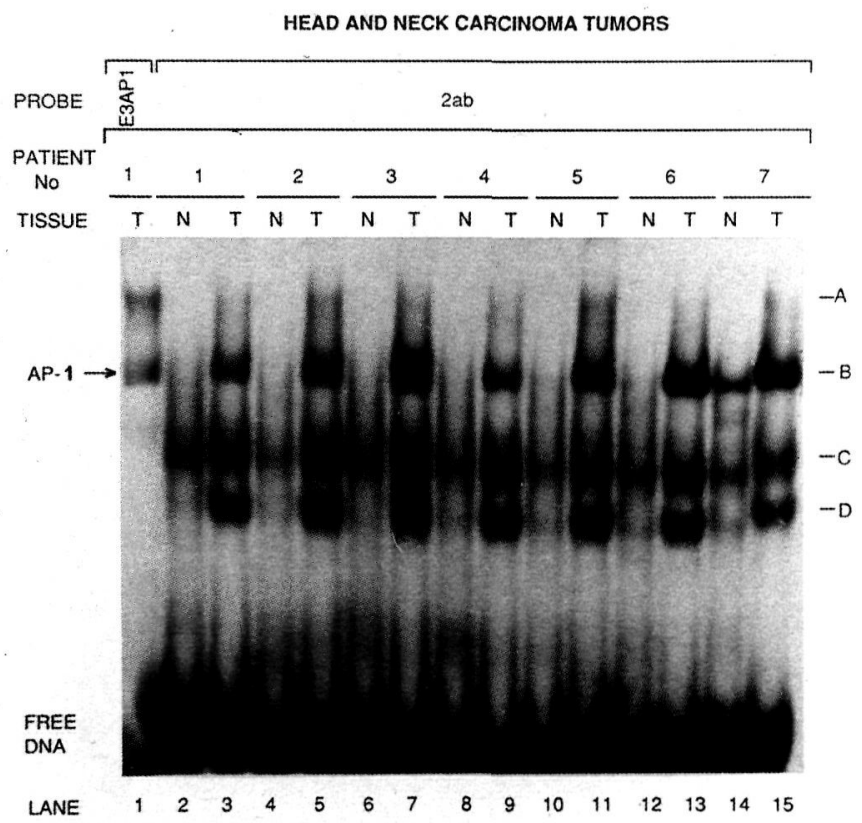

Figure 3. Electrophoretic mobility shift analysis using $\mathrm{E}_{3} \mathrm{AP}-1$ and 2ab-AP-1 binding consensus oligonucleotide. Nuclear extracts from head and neck carcinomas were incubated with $\gamma^{32} \mathrm{P}$-end-labelled $\mathrm{E}_{3} \mathrm{AP}-1$ and 2ab-AP-1 oligonucleotide hybrids (lanes 1 and 2-15, respectively). The DNA-AP-1 protein complex is indicated by the arrow. $\mathrm{N}=$ normal, $\mathrm{T}=$ tumor.

DNA-AP-1 protein complex formation. This is not surprising since $\mathrm{E}_{3} \mathrm{AP}-1$ contains the AP-1 binding consensus from the $\mathrm{E}_{3}$ promoter (37), while $1 \mathrm{ab}$ and $4 \mathrm{ab}$ are highly homologous $(71.5 \%)$ to the same sequence (34). However, the non-
Table I. pTNM, AP-1 level and stage of differentiation in tumors of lung cancer patients.

\begin{tabular}{clll}
\hline Patient No $^{\mathrm{a}}$ & pTNM $^{\mathrm{b}}$ & AP-1 level & $\begin{array}{c}\text { Stage of } \\
\text { differentiation }\end{array}$ \\
\hline 1 & $\mathrm{~T}_{3} \mathrm{~N}_{1} \mathrm{M}_{0}$ & elevated & III \\
2 & $\mathrm{~T}_{2} \mathrm{~N}_{1} \mathrm{M}_{0}$ & elevated & II \\
3 & $\mathrm{~T}_{2} \mathrm{~N}_{0} \mathrm{M}_{0}$ & non-elevated & I \\
4 & $\mathrm{~T}_{2} \mathrm{~N}_{0} \mathrm{M}_{0}$ & elevated & III \\
5 & $\mathrm{~T}_{1} \mathrm{~N}_{0} \mathrm{M}_{0}$ & non-elevated & I \\
6 & $\mathrm{~T}_{3} \mathrm{~N}_{2} \mathrm{M}_{0}$ & elevated & III \\
7 & $\mathrm{~T}_{2} \mathrm{~N}_{2} \mathrm{M}_{0}$ & elevated & III \\
8 & $\mathrm{~T}_{4} \mathrm{~N}_{2} \mathrm{M}_{0}$ & elevated & II \\
9 & $\mathrm{~T}_{2} \mathrm{~N}_{1} \mathrm{M}_{0}$ & elevated & II \\
10 & $\mathrm{~T}_{2} \mathrm{~N}_{0} \mathrm{M}_{0}$ & non-elevated & I \\
11 & $\mathrm{~T}_{2} \mathrm{~N}_{0} \mathrm{M}_{0}$ & elevated & II \\
12 & $\mathrm{~T}_{2} \mathrm{~N}_{1} \mathrm{M}_{0}$ & elevated & III \\
& & & \\
\hline
\end{tabular}

${ }^{a}$ All tissue specimens were obtained from lung cancer patients. ${ }^{b}$ pTNM was defined according to the UICC classification. 'Tumor/adjacent normal tissue.

Table II. pTNM, AP-1 level and stage of differentiation in tumors of bladder cancer patients.

\begin{tabular}{rlll}
\hline Patient No $^{\mathrm{a}}$ & $\mathrm{pTNM}^{\mathrm{b}}$ & AP-1 level & $\begin{array}{c}\text { Stage of } \\
\text { differentiation }\end{array}$ \\
\hline 1 & $\mathrm{~T}_{3} \mathrm{~N}_{0} \mathrm{M}_{0}$ & elevated & III \\
2 & $\mathrm{~T}_{0} \mathrm{~N}_{0} \mathrm{M}_{0}$ & non-elevated & $\mathrm{I}$ \\
3 & $\mathrm{~T}_{2} \mathrm{~N}_{0} \mathrm{M}_{0}$ & elevated & II \\
4 & $\mathrm{~T}_{3} \mathrm{~N}_{0} \mathrm{M}_{0}$ & elevated & III \\
5 & $\mathrm{~T}_{3} \mathrm{~N}_{0} \mathrm{M}_{0}$ & elevated & III \\
6 & $\mathrm{~T}_{1} \mathrm{~N}_{0} \mathrm{M}_{0}$ & elevated & II \\
7 & $\mathrm{~T}_{0} \mathrm{~N}_{0} \mathrm{M}_{0}$ & non-elevated & I \\
8 & $\mathrm{~T}_{0} \mathrm{~N}_{0} \mathrm{M}_{0}$ & non-elevated & I \\
9 & $\mathrm{~T}_{1} \mathrm{~N}_{0} \mathrm{M}_{0}$ & elevated & II \\
10 & $\mathrm{~T}_{0} \mathrm{~N}_{0} \mathrm{M}_{0}$ & non-elevated & I \\
11 & $\mathrm{~T}_{2} \mathrm{~N}_{0} \mathrm{M}_{0}$ & elevated & II \\
12. & $\mathrm{~T}_{0} \mathrm{~N}_{0} \mathrm{M}_{0}$ & non-elevated & I \\
13 & $\mathrm{~T}_{1} \mathrm{~N}_{0} \mathrm{M}_{0}$ & elevated & II \\
14 & $\mathrm{~T}_{2} \mathrm{~N}_{0} \mathrm{M}_{0}$ & elevated & II \\
& & &
\end{tabular}

${ }^{\mathrm{a} A l l}$ tissue specimens were obtained from bladder cancer patients. b pTNM was defined according to the UICC classification. 'Tumor/adjacent normal tissue.

labelled oligonucleotide hybrid 3ab did not compete for AP-1 binding activity with the labelled oligonucleotide hybrids $2 \mathrm{ab}$ and $1 \mathrm{ab}$, presumably because it shares only a limited homology $(57.1 \%)$ to the AP-1 concensus.

The non-labelled oligonucleotide hybrids $\mathrm{E}_{3} \mathrm{AP}-1$, 1ab, $2 \mathrm{ab}$ and $4 \mathrm{ab}$ competed with the labelled oligonucleotide 
Table III. pTNM, AP-1 level and stage of differentiation of head and neck tumors.

\begin{tabular}{cccc}
\hline Patient No $^{\mathrm{a}}$ & $\mathrm{pTNM}^{\mathrm{b}}$ & AP-1 level $^{\mathrm{c}}$ & $\begin{array}{c}\text { Stage of } \\
\text { differentiation }\end{array}$ \\
\hline 1 & $\mathrm{~T}_{3} \mathrm{~N}_{0} \mathrm{M}_{0}$ & elevated & II \\
2 & $\mathrm{~T}_{3} \mathrm{~N}_{1} \mathrm{M}_{0}$ & elevated & III \\
3 & $\mathrm{~T}_{2} \mathrm{~N}_{2} \mathrm{M}_{0}$ & elevated & IV \\
4 & $\mathrm{~T}_{3} \mathrm{~N}_{1} \mathrm{M}_{0}$ & elevated & III \\
5 & $\mathrm{~T}_{2} \mathrm{~N}_{0} \mathrm{M}_{0}$ & elevated & II \\
6 & $\mathrm{~T}_{2} \mathrm{~N}_{0} \mathrm{M}_{0}$ & elevated & II \\
7 & $\mathrm{~T}_{2} \mathrm{~N}_{0} \mathrm{M}_{0}$ & elevated & II
\end{tabular}

${ }^{a}$ All tissue specimens were obtained from head and neck cancer patients. ${ }^{b}$ pTNM was defined according to the UICC classification. cTumor/adjacent normal tissue.

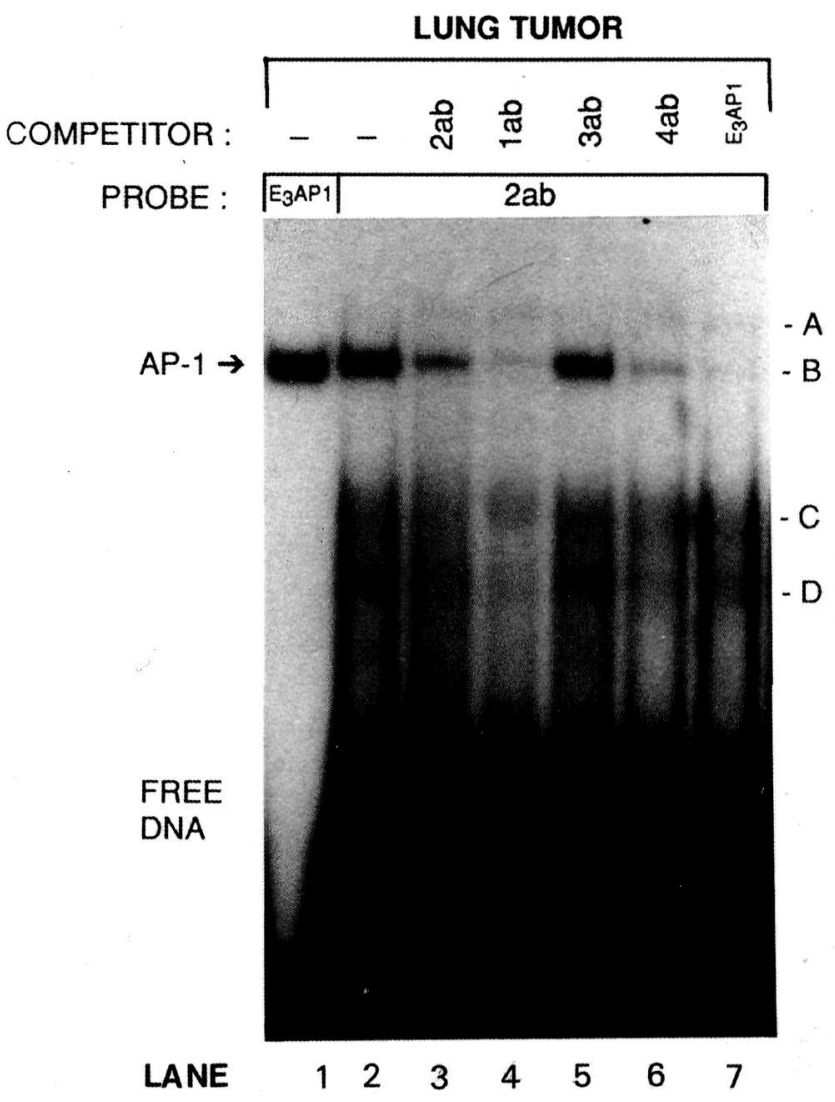

Figure 4. Effect of competitor sequences on gel electrophoretic mobility shift. Nuclear extracts from lung tumors were incubated with $\gamma^{32} \mathrm{P}$-end labelled $\mathrm{E}_{3} \mathrm{AP}-1$ and 2ab-AP-1 oligonucleotide hybrids, respectively (lanes 1 and 2-7). In competition assays, 200-fold excess of cold competitor oligonucleotides 2ab, 1ab, 3ab, 4ab and $\mathrm{E}_{3} \mathrm{AP}-1$ (lanes 3-6 and 7, respectively), were incubated with the nuclear extracts before adding the probe. The DNA-AP-1 protein complex is indicated by the arrow.

$\mathrm{E}_{3} \mathrm{AP}-1$ for DNA-AP-1 protein complex formation (Fig. 7, lung tumor). In Fig. 8 the effect of JUN antibody on the formation of the DNA-protein complex between $\mathrm{E}_{3} \mathrm{AP}-1$ or $2 \mathrm{ab}$ oligo and the AP-1 protein from bladder tumor nuclear extracts is shown.

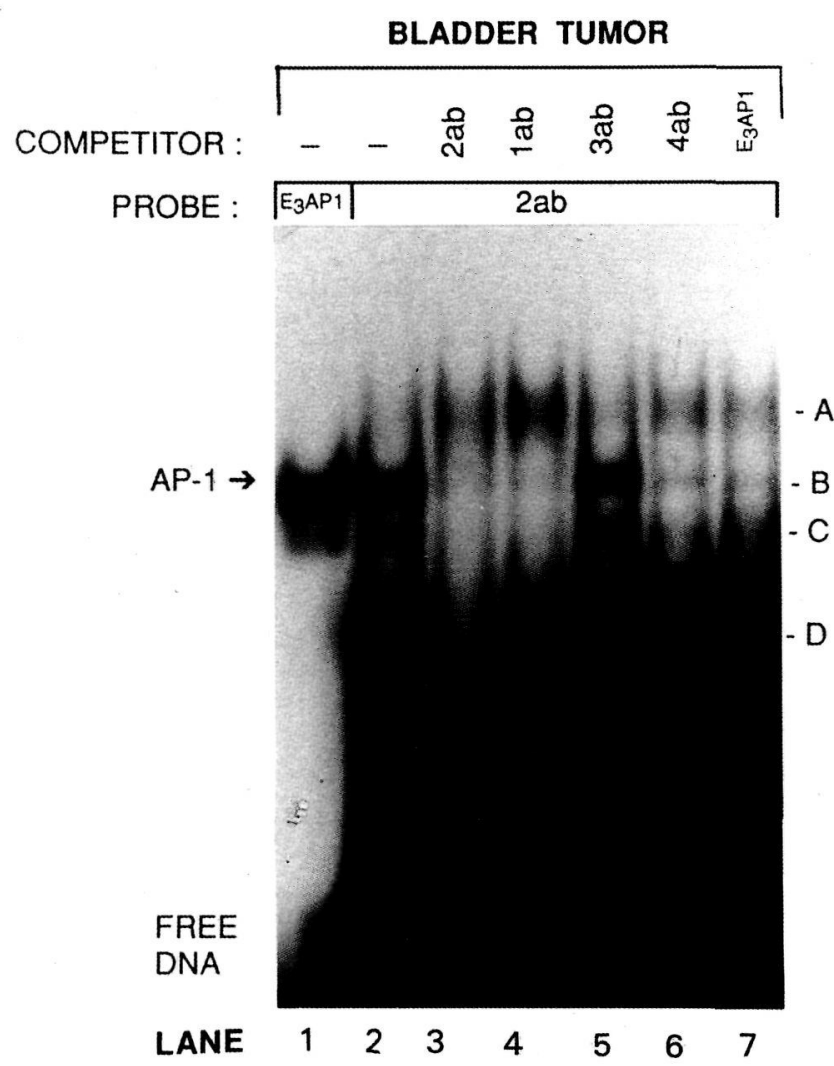

Figure 5. Effect of competitor sequences on gel electrophoretic mobility shift. Nuclear extracts from bladder tumors were incubated with $\gamma^{32} \mathrm{P}$-end labelled $\mathrm{E}_{3}$ AP-1 and 2ab-AP-1 oligonucleotide hybrids, respectively (lanes 1 and 2-7). In competition assays, 200-fold excess of cold competitor oligonucleotides $2 \mathrm{ab}, 1 \mathrm{ab}, 3 \mathrm{ab}, 4 \mathrm{ab}$ and $\mathrm{E}_{3} \mathrm{AP}-1$ (lanes 3-7) were incubated with the nuclear extracts before adding the probe. The DNA-AP-1 protein complex is indicated by the arrow.

\section{Discussion}

The human immunodeficiency virus type 1 long terminal repeat, HIV-1 LTR, contains binding sites for several cellular transcription factors which contribute to HIV-1 gene expression. The interaction between cellular and viral proteins and DNA sequences of the HIV-1 LTR is proposed to play a crucial role in transactivating HIV- 1 and in inducing the switch from latency to virus production and phenotypic appearance of cytopathic effects.

A number of studies have indicated that the AP-1 site is an important component of several regulatory regions. Functionally important AP-1 sites have been identified in the enhancer of the chicken B-globin (38), metallothionein IIa (39) and collagenase genes (40); in the polyomavirus enhancer (41), and in the human $\beta$-globin dominant control region (42). Furthermore, AP-1 binding sites have also been identified in the genome of the visna virus closely related to HIV-1 where they play a critical role in basal activity and transactivation of the viral LTR by the virally encoded TAT protein (43).

In a previous study we identified three newly elucidated AP-1 binding sites in the HIV-1 LTR using in gel retardation assays nuclear extracts from MDA MB 468 and HeLa tumor cells (34). In the present study we examined the gel mobility shift assays with the same synthetic oligonucleotides 


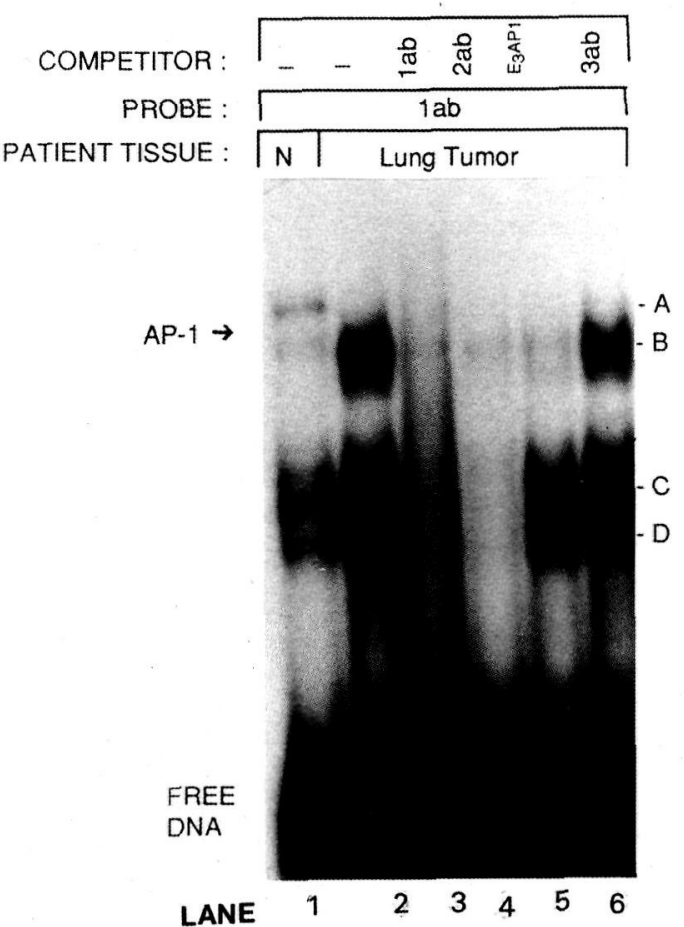

Figure 6. Effect of competitor sequences on gel electrophoretic mobility shift. Nuclear extracts from lung tumors and adjacent normal tissues (lanes 2-6 and 1, respectively), were incubated with $\gamma^{32} \mathrm{P}$-end labelled 1ab-AP-1 oligonucleotide hybrid. In competition assays, 200-fold excess of cold competitor oligonucleotides $1 \mathrm{ab}, 2 \mathrm{ab}, \mathrm{E}_{3} \mathrm{AP}-1$ and $3 \mathrm{ab}$ (lanes 3-6), were incubated with the nuclear extracts before adding the probe. Only the specific retarded bands of interest are shown.

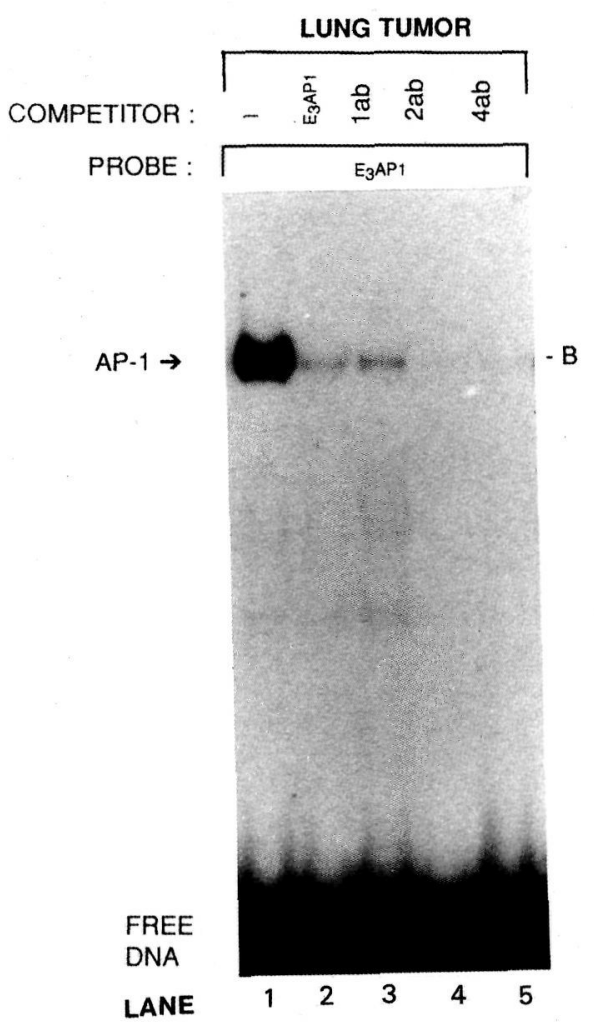

Figure 7. Effect of competitor sequences on gel electrophoretic mobility shift. Nuclear extracts from lung tumors were incubated with $\gamma^{32} \mathrm{P}$-end labelled $\mathrm{E}_{3} \mathrm{AP}-1$ oligonucleotide hybrid. In competition assays, 200-fold excess of cold competitor oligonucleotides $\mathrm{E}_{3} \mathrm{AP}-1 \mathrm{1ab}, 2 \mathrm{ab}$ and $4 \mathrm{ab}$ (lanes 2-5) were incubated with the nuclear extracts before adding the probe. Only the specific retarded bands of interest are shown.

\section{BLADDER TUMOR}

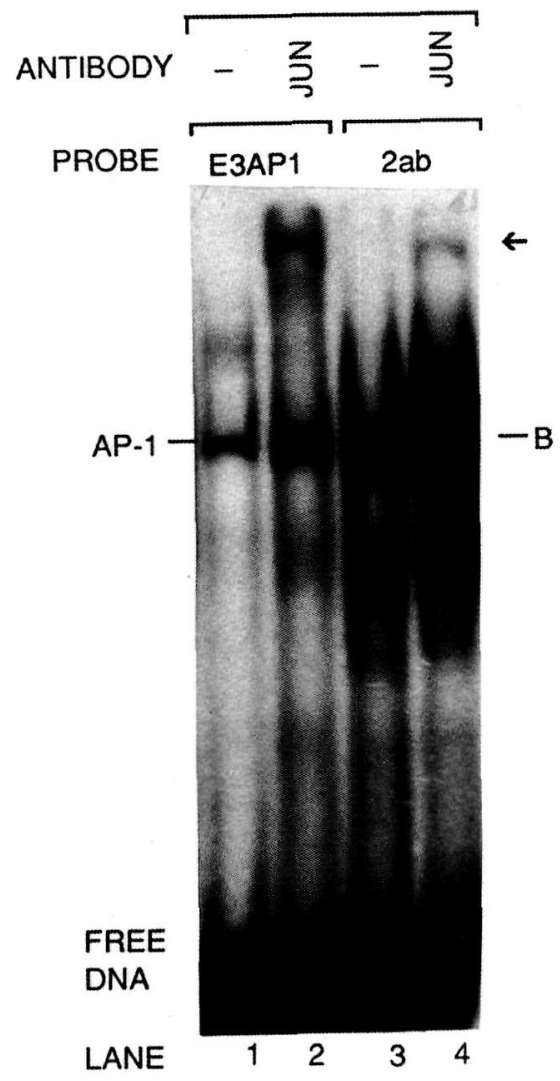

Figure 8. Effect of JUN antibody on the AP-1/oligonucleotide complexes studied by gel electrophoretic mobility shift assays. Nuclear extracts from bladder tumors were incubated with $\mathrm{E}_{3} \mathrm{AP}-1$ oligonucleotide (lane 1) and 2 ab oligonucleotide (lane 3 ). JUN antibody and nuclear extracts from bladder tumors were incubated with $\mathrm{E}_{3} \mathrm{AP}-1$ oligonucleotide (lane 2) and $2 \mathrm{ab}$ oligonucleotide (lane 4 ), respectively. The shift in the mobility of the JUN complex is shown.

containing the putative HIV-1 LTR AP-1 sites and nuclear extracts from human lung, bladder and head and neck tumors. Several studies have suggested that AP-1 activity may be important in cell regulation and growth $(44,45)$. In the present study we report that AP-1 activity is elevated in $75 \%$ of lung tumors, $66.6 \%$ of bladder tumors and in $100 \%$ of head and neck carcinomas examined as compared to adjacent normal tissue. These and other results (46-48) suggest that the products of $j u n$ and fos oncogenes represent a class of inducible cellular proteins that could modulate the expression of genes containing AP-1 binding sites since previous studies have demonstrated that there is elevated expression of the oncogenes $\mathrm{H}-$ ras and $\mathrm{K}$-ras in the development of squamous cell carcinoma of the head and neck $(49,50)$. It is therefore plausible that the increased levels of AP-1 we have observed in breast, bladder, lung and head and neck human tumors (47-51) are due to ras activation which triggers fos (52) and JUN/AP-1 (53) gene expression. Therefore, it would be of interest to examine whether a correlation between ras, jun and fos expression and tumor stage exists.

A comparision of AP-1 activity and pTNM was carried out for lung, bladder and head and neck tumors (Table I, II and III) as described previously in studies for human lung and bladder tumors (48). Although the number of samples 
analysed was relatively small, a correlation was found between the stage of differentiation and AP-1 levels in head and neck tumors. The higher the stage of differentiation the higher the AP-1 levels (48).

The importance of AP-1 in the regulation of HIV-1 gene expression can only be speculated on. Many agents that induce transcription of latent, proviral DNA or reporter gene linked to the HIV-1 LTR (6-16) also induce a substantial level of fos expression $(54,55)$. Although no causal link between these two phenomena has been demonstrated it is possible that AP-1 family proteins which represent a class of inducible cellular proteins could play a role in the transcriptional regulation of human immunodeficiency virus type 1 gene expression.

\section{References}

1. Barre-Sinousi F, Cherman JC, Rey F, Huyeyre MT, Chamaret S, Gruest J, Dauguet C, Alxer-Blin C, Venizet-Brun F, Rouzioux C, Rosenbaum W and Montagnier L: Isolation of a T-lymphotropic retrovirus from a patient at risk for acquired immunodeficiency syndrome (AIDS). Science 220: 868-871, 1983.

2. Gallo RC, Salahuddin SZ, Popovic M, Shearer GM, Kaplan M, Haynes BF, Palker TJ, Redfield R, Oleske J, Safai B, White G, Foster P and Markhan PD: Frequent detection and isolation of cytopathic retrovirus (HTLV-II) from patients with AIDS and at risk for AIDS. Science 224: 500-503, 1984.

3. Levy SA, Hoffman AD, Kramer SM, Landis JA, Shimabukuro JM and Oshiro LS: Isolation of lymphocytopathic retrovirus from San Francisco patients with AIDS. Science 225: 840-842, 1984.

4. Varmus H: Regulation of HIV and HTLV gene expression. Gene Develop 2: 1055-1062, 1988.

5. Rosen CA: Regulation of HIV gene expression by RNA-protein interactions. Trends Genet 7: 9-14, 1991.

6. Vaishnav YN and Wong-Staal F: The biochemistry of AIDS. Ann Rev Biochem 60: 577-630, 1991.

7. Spandidos DA, Yiagnisis $M$ and Pintzas A: Human immunodeficiency virus long terminal repeat responds to transformation by the mutant T24 H-ras 1 oncogene and it contains multiple AP-1 binding TPA-inducible consensus sequence elements. Anticancer Res 9: 383-386, 1989.

8. Spandidos DA, Zoumpourlis V, Kotsinas A, Tsiriyotis C and Sekeris CE: Response of human immunodeficiency virus long terminal repeat to growth factors and hormones. Anticancer Res 10: 1241-1246, 1990.

9. Zoumpourlis V, Eliopoulos A and Spandidos DA: Transcriptional activation of the human immunodeficiency virus long terminal repeat sequences by tumor necrosis factor. Anticancer Res 12: 2065-2068, 1992.

10. Spandidos DA, Zoumpourlis V, Kotsinas A, Maurer HR and Patsilinakos P: Transcriptional activation of the human immunodeficiency virus long terminal repeat sequences by cisplatin. Gen Anal Techn Appl 7: 138-141, 1990.

11. Zoumpourlis V, Patsilinakos P, Kotsinas A, Maurer HR, Lenas P and Spandidos DA: Cis-platin stimulates the expression from the human immunodeficiency virus long terminal repeat sequences in human fibroblasts. Anti-Cancer Drug 1: 55-58, 1990.

12. Zoumpourlis V, Kerr DJ and Spandidos DA: Differential interaction of cis-platin with the HIV-1 long terminal repeat in a resistant ovarian carcinoma cell line. Anti-Cancer Drug 4: 7783, 1993.

13. Zoumpourlis V, Kerr DJ and Spandidos DA: Doxorubicin stimulates transcription from the human immunodeficiency virus long terminal repeat sequences. Cancer Lett 56: 181-185, 1991.

14. Zoumpourlis V and Spandidos DA: Hexamethylene bisacetamide stimulates the expression of human immunodeficiency virus long terminal repeat sequences in rat and human fibroblasts. Anti-Cancer Drug 3: 163-167, 1992.

15. Zoumpourlis V and Spandidos DA: Mitomycin C stimulates the expression of human immunodeficiency virus long terminal repeat sequences in rat and human fibroblasts. Biochem Pharmacol 46: 178-181, 1993.
16. Zoumpourlis V, Kerr DJ and Spandidos DA: Carboplatin as opposed to cis-platin does not stimulate the expression of the human deficiency virus long terminal repeat sequences. Biochem Pharmacol 43: 650-654, 1992.

17. Garcia JA, Wu FK, Mistuyasu R and Gaynor RB: Interactions of cellular proteins involved in the transcriptional regulation of the human immunodeficiency virus. EMBO J 6: 3761-3770, 1987.

18. Jones KA, Kadonaya JT, Luciw PA and Tjian R: Activation of the AIDS retrovirus promoter by the cellular transcription factor Sp1. Science 232: 755-759, 1986.

19. Jones KA, Luciw PA and Duchange N: Structural arrangements of transcription control domains within the 5'-untranslated leader regions of the HIV-1 and HIV-2 promoters. Gene Develop 2: 1101-1104, 1988.

20. Wu FK, Garcia JA, Harrich D and Gaynor RB: Purification of the human immunodeficiency virus type 1 enhancer and TAR binding proteins EBP-1 and UBP-1. EMBO J 7: 2117-2129, 1988.

21. Nabel G and Baltimore D: An inducible transcription factor activates expression of human immunodeficiency virus in $\mathrm{T}$ cells. Nature 326: 711-713, 1987.

22. Franza BR, Josephs SF, Gilman MZ, Ryan W and Clarkson B: Characterization of cellural proteins recognizing the HIV enhancer using a microscale DNA-affinity precipitation assay. Nature 330: 391-395, 1987.

23. Shaw JP, Ultz PJ, Durand DB, Toole JJ, Emmel EA and Crabtree GR: Identification of a putative regulator of early $\mathrm{T}$ cell activation genes. Science 241: 202-205, 1988.

24. Franza BR, Rouscher FJ, Josephs SF and Curran T: The fos complex and fos-related antigens recognize sequence elements that contain AP-1 binding sites. Science 239: 1150-1153, 1988.

25. Nakabeppu Y, Ryder K and Nathans D: DNA binding activities of three murine jun proteins: stimulation by fos. Cell 55: 907$915,1988$.

26. Cohen DR and Curran T: Fra-1: a serum-inducible, cellular immediate-early gene that encodes a fos-related antigen. Mol Cell Biol 8: 2063-2069, 1988.

27. Rauscer FJ, Cohen DR, Bos TJ, Vogt PK, Bohmann D, Tjian R and Franza BR: Fos-associated protein p39 is the product of the jun proto-oncogene. Science 240: 1010-1016, 1988.

28. Chiu R, Boyle WJ, Meek J, Smeal T, Hunter T and Karin M: The c-fos protein interacts with c-jun/AP-1 to stimulate transcription of AP-1 responsive gene. Cell 54: 541-552, 1988.

29. Sassone-Corsi P, Lamph WN, Kamps M and Verma IM: Fosassociated cellular p39 is related to nuclear transcription factor AP-1. Cell 54: 553-560, 1988

30. Zerial M, Tosci L, Ryseck R, Schuerman M, Muller R and Bravo R: The product of a novel growth factor activated gene, fos $\mathrm{B}$, interacts with jun proteins enhancing their DNA binding activity. EMBO J 8: 805-813, 1989.

31. Curran T and Franza BR: Fos and jun: The AP-1 connection. Cell 55: 395-397, 1988.

32. Landschultz WH, Johnson PF and McKnight SL: The leukine zipper: A hypothetical structure common to a new class of DNA binding proteins. Science 240: 1759-1764, 1988.

33. Bohmann D, Bos TJ, Admon A, Nishimura T and Vogt PK: Human proto-oncogene c-jun encodes a DNA binding protein with structural and fuctional properties of transcription factor AP-1. Science 238: 1386-1392, 1987.

34. Zoumpourlis V, Ergazaki $M$ and Spandidos DA: AP-1 recognizes sequence elements on HIV-1 LTR in MDA MB 468 and HeLa tumor cell lines. Oncol Rep 1: 397-401, 1994.

35. Bradford MM: A rapid and sensitive method for the quantitation of microgram quantities of protein using the principle of protein-dye binding. Anal Biochem 72: 248-254, 1976.

36. Maniatis T, Fritsch EF and Sambrook J: Molecular Cloning: A Laboratory Manual. Cold Spring Harbor Laboratory, Cold Spring Harbor, NY, 1989.

37. Hurst $\mathrm{HC}$ and Jones NC: Identification of factors that interact with the E1A-inducible adenovirus $E_{3}$. Gene Develop 1: 1132$1146,1987$.

38. Reitman M and Felsenfeld G: Mutational analysis of the chicken $B$-globin enhancer reveals two positive-acting domains. Proc Natl Acad Sci USA 85: 6267-6271, 1988.

39. Lee W, Mitchell P and Tjian R: Purified transcription factor AP-1 interacts with TPA-inducible enhancer elements. Cell 49: 741$752,1987$.

40. Angel P, Baumann B, Stein H, Delius H, Rahmsdort J and Horrlich P: 12-O-tetradecanoyl-phorbol-13 acetate induction of 
the human collagenase gene is mediated by an inducible enhancer element located in the 5'-flanking region. Mol Cell Biol 7: 2256-2266, 1987.

41. Martin ME, Piette J, Yaniv M, Tany W-J and Folk WR: Activation of the polyomavirus enhancer by a murine activator protein 1 (AP-1) homolog and two contiguous proteins. Proc Natl Acad Sci USA 85: 5834-5843, 1988.

42. Ney PA, Sorrentino BP, McDonagh KT and Nienhuis AW: Tandem AP-1-binding sites within the human B-globin dominant control region function as an inducible enhancer in erythroid cells. Gene Develop 4: 993-1006, 1990.

43. Hess JL, Small JA and Clements JE: Sequences in the visna virus long terminal repeat that control transcriptional activity and respond to viral trans-activation: involvement of AP-1 sites in basal activity and trans-activation. J Virol 63: 3001-3015, 1989.

44. Gillespie DAF: fos and jun: oncogenes and transcription factor. Sem Virol 2: 329-339, 1991.

45. Vogt PK and Bos TJ: The oncogene jun and nuclear signalling. Trends Biochem Sci 14:172-175, 1989.

46. Reddy EP, Skalka AM and Curran T (eds): The Oncogene Handbook. Amsterdam, Elsevier Science Publishers, 1988.

47. Linardopoulos S, Malliri A, Pintzas A, Vassilaros S, Tsikkinis A and Spandidos DA: Elevated expression of AP-1 activity in human breast tumors as compared to normal adjacent tissue. Anticancer Res 10: 1711-1714, 1990.

48. Linardopoulos S, Papadakis E, Delakas D, Thoedosiou V, Cranidis $\mathrm{A}$ and Spandidos DA: Human lung and bladder carcinoma tumors as compared to their adjacent normal tissue have elevated AP-1 activity associated with the retinoblastoma gene promoter. Anticancer Res 13: 257-262, 1993.
49. Field JK, Lamothe A and Spandidos DA: Clinical relevance of oncogene expression in head and neck tumors. Anticancer Res 6: 595-600, 1986.

50. Field JK and Spandidos DA: Expression of oncogenes in human tumours with special reference to the head and neck region. $J$ Oral Pathol 16: 97-107, 1987.

51. Bos JL: The ras gene family and human carcinogenesis. Mutat Res 195: 265-271, 1988.

52. Wyllie AH, Rose KA, Morris RG, Steel CM, Foster E and Spandidos DA: Rodent fibroblast tumors expressing human $m y c$ and ras genes: Growth, metastasis and endogenous oncogene expression. Br J Cancer 56: 251-259, 1987.

53. Wasylyk C, Imler JL and Wasylyk B: Transforming but not immortalizing oncogenes activate the transciption factor PEA 1. EMBO J 7: 2475-2483, 1988.

54. Reed JC, Alpers JD, Nowell PC and Hoover RC: Sequential expression of proto-oncogenes during lectin-stimulated mitogenesis of normal human lymphocytes. Proc Natl Acad Sci USA 83: 3982-3986, 1986.

55. Pompidou A, Corral M, Michel P, Detec N, Kruh J and Curran T: The effects of phorbol ester and $\mathrm{Ca}$ ionophore of $\mathrm{c}$-fos and $\mathrm{c}$ $m y c$ expression and on DNA synthesis in human lymphocytes are not directly related. Biochem Biophys Res Commun 148: 435-442, 1987. 